\title{
How Does Immigration Affect Wages and the Unemployment Rate in Malaysia? A Computable General Equilibrium (CGE) Approach
}

\author{
Rusmawati Said ${ }^{1}$, Kamarul Hidayah Abdul Hamid ${ }^{1} \&$ Nursyazwani Mazlan ${ }^{1}$ \\ ${ }^{1}$ School of Business and Economics, Universiti Putra Malaysia, UPM Serdang, Selangor, Malaysia \\ Correspondence: Kamarul Hidayah Abdul Hamid, School of Business and Economics, Universiti Putra Malaysia, \\ 43400 UPM Serdang, Selangor, Malaysia. Tel: 603-9769-7580. E-mail: kamarulhidayah@yahoo.com
}

Received: October 8, 2020

Accepted: October 19, 2020

Online Published: October 31, 2020

doi:10.5539/ass.v16n11p100

URL: https://doi.org/10.5539/ass.v16n11p100

\begin{abstract}
Malaysia had approximately 2 million migrants in 2018, and this number was increasing dramatically by 25 percent in 2019. Parallels with the aims of country policy to reduce migrant workers' dependency in 2020 , managing the workers needs to be clarified. At the same time, the country still needs to keep them for specific sectors. These issues motivate us to analyze the migrant worker's requirements at different levels of skills and wages. Using Computable General Equilibrium (CGE) modeling, at four-level nested CES production function, this study found high skilled migrants will harm wages for the high skilled and skilled groups while the opposite effect was observed for the semiskilled and low-skilled groups. However, when the migrant stock increases slightly below 1 percent, it will reduce the wages for semiskilled workers due to substitution effects. This study also found that the influx of low-skilled migrant workers will reduce salaries for semiskilled and low-skilled workers. The analysis also indicates that a small rise in high skilled immigrant labour will reduce the unemployment rate; likewise, increasing more than 4 percent will increase the unemployment rate. The results provide the policymaker guidelines to employ foreign workers' best skills to control the inequality of wages among skilled and low-skilled workers.
\end{abstract}

Keywords: immigration labour, CGE, wages, unemployment rate

\section{Introduction}

In the new global economy, migrant worker's issues have become an essential factor and a treat for local workers, especially in wages and skills needed. According to Card, 2009, and Borjas et al., 2014, migrant workers' impact on wages and employment levels are highlighted significantly. Migrant workers will give some economically beneficial to a country's growth and development. However, the economic benefits are not equal for all countries, depending on migrants' size and characteristics. Edo (2019) claimed that the composition of immigrant skills is a significant element in assessing their effect on the local labour market outcomes. Immigration inflows tend to decrease the wages of competing local workers (with skills equivalent to those of migrants) and to raise the wages of complementary workers.

High skilled and skilled Malaysians benefit immensely from migrant workers' involvement, but semiskilled Malaysians have negative wage and employment impacts (McNabb \& Said, 2013). Malaysia is no exception to this scenario. A developed country like the United States and other OECD countries are receiving both the higher and lower ends of the skills distribution (Docquier, Ozden, \& Peri, 2010) and migrate with spouse and dependents. They also have the opportunity to assimilate, obtain permanent residency, and eventually become citizens. This assimilation process creates another type may become more similar to the local. On the other hand, migrants to Malaysia are overwhelmingly low-skilled. The vast majority of migrant workers are only legally permitted to stay in Malaysia for a maximum of five years without bringing any dependents.

The International Food Policy Research Institutes (IFPRI) has been widely used in the Computable General Equilibrium (CGE) for policy analysis. This study defines the imperfect labour market by expanding the traditional IFPRI CGE model structure (Lofgren et al., 2002) using four level nested CES production functions. Based on the IO 2010 table on a 32×32 SAM dataset, the model was calibrated. This finding contributes to a growing body of literature responding to the influx of migrant workers to the labour market outcome through different skill categories. Among the most recent studies are Borjas (2003) and Borjas et al. (2014), which found a significant negative wage effect for local workers. In comparison, Card (2009) and Ottaviano and Peri (2012) 
maintained that it is relatively small and often optimistic about having the same effect. Most of the debate on migrant workers centered on the elasticity of substitution between workers in different skill groups and the impact on relative salaries as the relative abundance of different types of jobs is changed by immigration. Nevertheless, we presumed that in this study, the elasticity of substitution was infinite. We categorized labour into four categories of skills: high skilled, skilled, semiskilled, and low-skilled.

This paper also highlights a noticeable gap in the literature, where current literature is almost exclusively limited to OECD countries. However, nearly half of global immigration happens in countries outside the OECD. Focusing on migration studies of migrant workers in developed countries such as Europe and America, well-recorded studies have been published on immigration issues (Sharpe \& Bollinger, 2020; Diaz \& Ore, 2020; Del Boca \& Venturini, 2003; Lewer \& Van De Berg, 2008; Mayda, 2009). Compared to the driving force of employment migration, migration to developed countries (Europe and America) are more generally driven by the recipient countries' economic attractiveness factors.

Meanwhile, studies on migrant labour in developing countries, especially in the ASEAN region, are still limited. Research on immigrants to Malaysia is micro and qualitative (Devadason \& Meng, 2010; Kanapathy, 2004, 2008; Widyawati, 2008). Specific investigations on labour migration from Indonesia to Malaysia were conducted by Mantra (2000), Wahyuni (2005), Yusuf (2008), and May (2006). These studies were qualitative and focused solely on Indonesian migrant workers in a specific country. Similar qualitative investigations on the migration of Bangladeshi workers to Malaysia were conducted by Abdul Aziz (2001), Sultana (2007), and Ullah (2007). Unlike the others, this paper constructed a Social Accounting Matrix (SAM) using the Input-Output (IO) table of 2010, the simulation's base year.

This paper calibrated the model using benchmark data year 2010 using CGE methodology and simulated it into three classes. The first class (Class A) simulates the effect of a small-scale rise in the national labour supply. The second class (Class B) simulated on a large scale of the rising national labour supply affected by immigration. The third class (Class C) simulated the decline in the national supply of labour affected by migrant labour decline. The findings showed that certain skilled migrant labour types would encourage labour market competition, lower wages, and raise total labour unemployment. On the contrary, it positively affected the wage of complementary labour. The analysis also indicates that only a small rise in highly-skill led immigrant labour could reduce the total unemployment rate, though a large-scale increase would negatively affect.

The next section introduces the basic model framework and reviews the aggregate production function with a four-level nested-CES model. Section 3 presents the data and describes how to compute the relevant variables and calibration process. Section 4 presents the simulation results regarding the effects of immigration on labour market outcomes and sensitivity analysis. Section 5 concludes the paper.

\section{Method}

On the output production function, this paper used the Computable General Equilibrium (CGE) model by using the Neoclassical model approach (Dervis et al., 1982). The International Food Policy Research Institutes (IFPRI) then introduced an expanded model, which considers the basic labour market block. Using IFPRI's basic framework, this study expands the detailed definition of the labour market by considering four nested CES output production functions, taking into account employment across multiple sectors. The technical methodology went through four steps of development. The first step was to create a model based on the assumptions of a representative agent. Based on the IO 2010 table, the second step was to build the benchmark dataset using the developed SAM table, and the third step was to determine exogenous elasticity. The last move was to calibrate the benchmark data and perform the simulation with exogenous elasticity. The following figure illustrates the steps of technical CGE Modelling. 


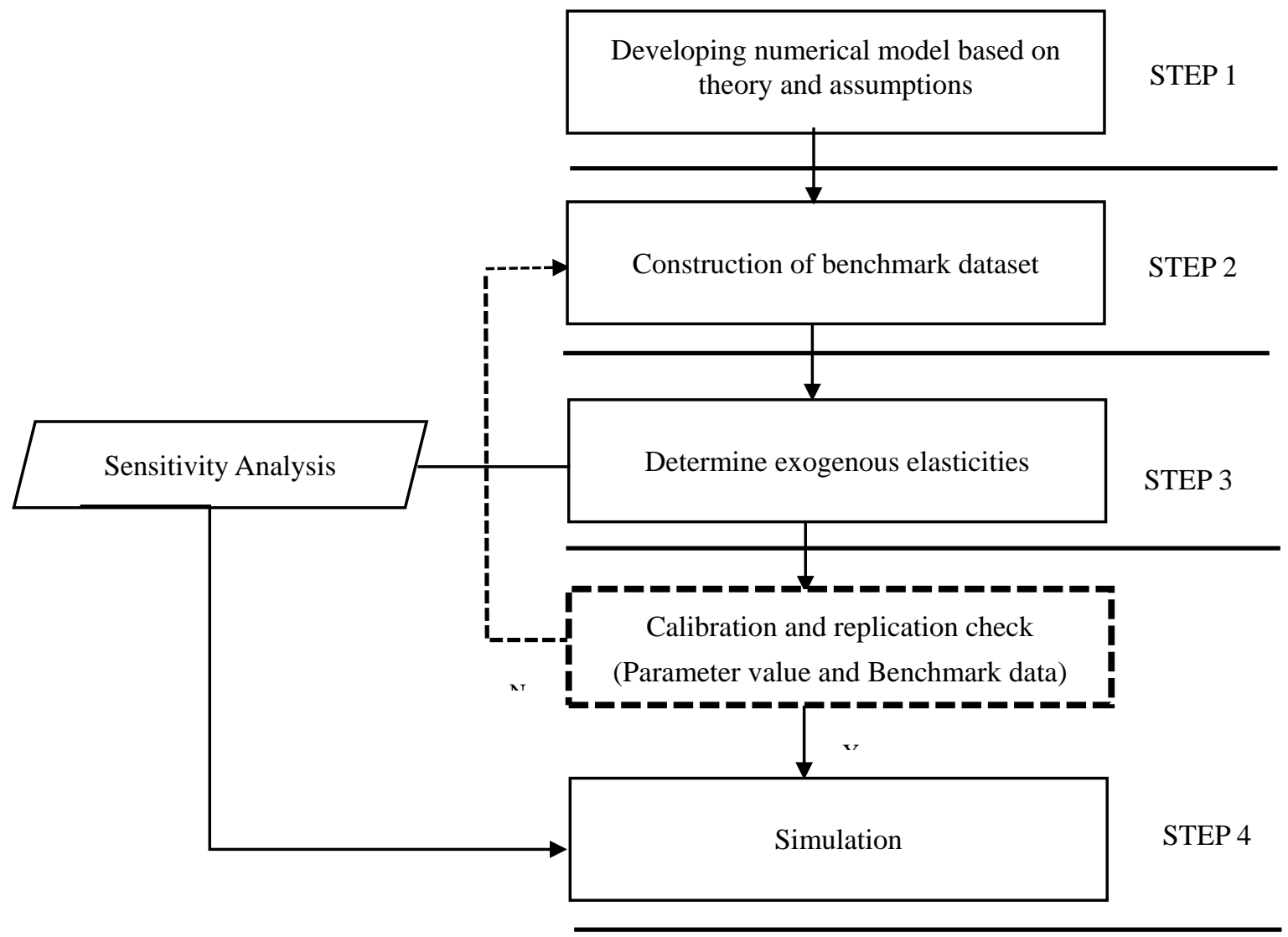

Figure 1. Steps of CGE Modelling

Sources: Author Illustration

\section{Step 1: Developing a numerical model based on theory and assumptions}

The model was built based on CES production functions. Optimal combinations of each aggregate factor measured by the first-order condition based on relative prices. The presumption of capital and of all kinds of labour is not equally substitutable. Given the labor market's imperfection, this model assumes that labour supply is equal to labor demand from all activities plus unemployment. The equations for the production are as follows:

CES function for level 1:

$$
Q A_{a}=a_{a}^{a} \cdot\left(\delta_{a}^{a} \cdot Q V A_{a}^{-\rho_{a}^{a}}+\left(1-a_{a}^{a}\right) \cdot Q I N T A_{a}^{-\rho_{a}^{a}}\right)^{\frac{1}{-\rho_{a}^{a}}}
$$

Value-added intermediate-input quantity ratio:

$$
\frac{Q V A_{a}}{\operatorname{QINTA}_{a}}=\frac{P I N T A_{a}}{P V A_{a}} \cdot{\frac{\delta_{a}^{a}}{1-\delta_{a}^{a}}}^{\frac{1}{1-\rho_{a}^{a}}}
$$

Equations (1) and (2) are the CES functions for the first level, which is the activity of output $\left(Q A_{a}\right)$ is determined by the quantity of value-added $\left(Q V A_{a}\right)$ and intermediate inputs $\left(Q I N T A_{a}\right) . a_{a}^{a}$ is the parameter of efficiency, $\delta_{a}^{a}$ is the shared parameter, and $\rho_{a}^{a}$ is the exponent of elasticity of substitution.

CES function for level 2:

$$
Q A_{a}=a_{a}^{v a} \cdot\left(\sum_{f \in F 1 S T} \delta_{f 1 s t a}^{v a} \cdot Q F_{f 1 s t a}^{-\rho_{a}^{v a}}\right)^{\frac{1}{-\rho_{a}^{v a}}}
$$

$W F_{f 1 s t} \cdot \overline{W F D I S T}_{f 1 s t a}$

$$
=P V A_{a} \cdot\left(1-t v a_{a}\right) \cdot Q V A_{a} \cdot\left(\sum_{f \in F 1 S T} \delta_{f 1 s t a}^{v a} \cdot Q F_{f 1 s t a}^{-\rho_{a}^{v a}}\right)^{-1} \cdot \delta_{f a}^{v a} \cdot Q F_{f 1 s t a}^{-\rho_{a}^{v a}-1}
$$


The quantity of value-added $\left(Q V A_{a}\right)$ is calculated in the second level CES function, disaggregated variables,

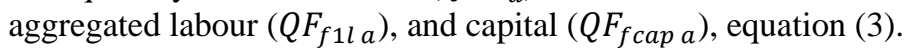

The ratio of factor payments to factor one (WFDIST) represents non-homogeneous factors. It is set in the first-order condition for profit maximization. It is directly derived from the first order for profit maximization as equality of pay rates between each activity factor and the marginal values for each factor in each activity. (McDonald, 2003). Equation (4) means that both activity production $\left(Q A_{a}\right)$ and factor demands are addressed through the profit maximization process.

CES function for level 3:

$$
Q F_{f 1 l a}=a_{f 1 l a}^{l a b} \cdot\left(\sum_{f \in F 1 L} \delta_{f 1 l a}^{l a b} \cdot Q F_{f 1 l a}^{-\rho_{f 1 l a}^{l a b}}\right)^{\frac{1}{-\rho_{f 1 l a}^{l a b}}}
$$

$W F_{f 2 n d} \cdot \overline{W F D I S T}_{f 2 n d a}$

$W F_{f 2 n d} \cdot \overline{W F D I S T}_{f 2 n d a} \cdot\left(\sum_{f \in F 2 N D} \delta_{f 1 l f 2 n d a}^{l a b} \cdot Q F_{f 2 n d a}^{-\rho_{a}^{l a b}}\right)^{-1} \cdot \delta_{f 1 l f 2 n d a}^{l a b} \cdot Q F_{f 2 n d a}^{-\rho_{f 1 l a}^{l a b} a^{-1}}=$

$a \in A C E S, f \in F 2 N D(6)$

$$
Q F_{f 2 l a}=a_{f 2 l a}^{l s k} \cdot\left(\sum_{f \in F 2 L} \delta_{f 2 l a}^{l s k} \cdot Q F_{f 2 l a}^{-\rho_{f 2 l a}^{l s k}}\right)^{\frac{1}{-\rho_{f 2 l a}^{l s k}}}
$$

Equation (5) is the third level feature for CES aggregation, which outlines the relationship between higher- and lower-skilled labour. As shown in equation (6), the wages of both kinds of work are calculated by maximizing profit. CES function for level 4 of the higher-skilled group:

$W F_{f l s k} \cdot \overline{W F D I S T}_{\text {flsk } a}$

$W F_{f 2 l a} \cdot \overline{W F D I S T}_{f 2 l a} \cdot\left(\sum_{f \in F L S K} \delta_{f 2 l \text { flsk } a}^{l s k} \cdot Q F_{f l s k a}^{-\rho_{a}^{l s k}}\right)^{-1} \cdot \delta_{f 2 l \text { flsk } a}^{l s k} \cdot Q F_{f l s k a}^{-\rho_{f 2 l a}{ }^{-1}}=$

$a \in A, f \in F L S K(8)$

$$
Q F_{f 3 l a}=a_{f 3 l a}^{\text {lusk }} \cdot\left(\sum_{f \in F 3 L} \delta_{f 3 l a}^{l u s k} \cdot Q F_{f 3 l a}^{-\rho_{f 3 l a}^{\text {lusk }}}\right)^{\frac{1}{-\rho_{f 3 l a}^{\text {lusk }}}}
$$

CES function for level 4 of the lower-skilled group:

$W F_{\text {flusk }} \cdot \overline{W F D I S T}_{\text {flusk } a}$

$W F_{f 3 l a} \cdot \overline{W F D I S T}_{f 3 l a} \cdot\left(\sum_{f \in F L U S K} \delta_{f 3 l \text { flusk } a}^{\text {lusk }} \cdot Q F_{\text {flusk } a}^{-\rho_{a}^{\text {lusk }}}\right)^{-1} \cdot \delta_{\text {f3l flusk } a}^{\text {lusk }} \cdot Q F_{\text {flusk } a}^{-\rho_{f 3 l a}^{\text {lusk }}=1}=$

$a \in A, f \in F L U S K(10)$

Equation (7) for the combining of high skilled (L1) and skilled (L2) labour at the fourth level of CES into higher-skilled (FLSK) labour, equation (9) for the combining of semiskilled (L3) and low-skilled- (L4) labour into lower-skilled (FLUSK) workers. They describe the maximization of profits in equations (8) and (10). The efficiency parameter $(\alpha)$ and the shared parameter $(\delta)$ are calibrated in these four-level CES, while the exponent of substitution elasticity $(\rho)$, determined from substitution elasticity $(\sigma)$, is estimated from external sources. 
Four Nested CES Functions: At the sectorial level, value-added is a nested constant elasticity of substitution (CES) function of Capital and Labour. The Labour aggregate is disaggregated into four bundles: low-skilled bundle (L4), semiskilled bundle (L3), skilled bundle (L2), and high skilled bundle (L1). The nested production structure allows for differentiated elasticities of substitution between various factors of production.

At the first level, quantities of value-added $\left(Q V A_{a}\right)$ and aggregate intermediate inputs $\left(Q I N T A_{a}\right)$ than activity output $\left(Q A_{a}\right)$ is specified by using CES. At the second level, the Leontief function of disaggregated intermediate input determines aggregate intermediate input.

The CES nest production functions of the third and fourth levels concentrate primarily on the four different forms of labour used in this paper, namely high skilled (L1), skilled (L2), semiskilled (L3), and low-skilled (L4). This study classifies these four types of labour into two labour groups. The aggregate labour force forms these two groups of aggregate labour, both substitutable $\left(Q F_{f l l}\right.$ a $)$ by the third level CES. Starting from the fourth level of the value added of CES production function, the substitutable high skilled (L1) and skilled (L2) group into aggregate higher-skilled labour. The substitutable semiskilled (L3) and low-skilled (L4) group into the aggregate lower-skilled labour.

Imperfect Labour Market: The wage curve was developed and formulated in many CGE modeling areas based on the passed analysis. Bohringer and Loschel (2006) and Kuster et al. (2007) used the wage curve in energy policy. Models that use the wage curve in analyzing sustainability trade and international labour migration can be found in Brucker and Kohlhaas (2004), Carneiro and Abbache (2003), and Baas and Brucker (2008). The analysis of poverty and income distribution also used the wage curve formula (e.g., Cury et al., 2004; Magubu \& Chitiga, 2007; Davies \& Rattso, 2000). Wu (2011) applied the wage curve theory in analyzing immigration to the UK.

The standard wage curve $\ln \mathrm{W}=\beta \ln U$ calls for further modification to obtain a wage equation that is appropriate for implementing the wage curve and its related involuntary unemployment. With Blanchflower and Oswald (1995), the $\beta$ parameter's elasticity is approximately -0.1 for every area or country, which means that a one percent rise in unemployment is correlated with a 0.1 percent drop in wages. The elasticity parameter per wage curve was set at -0.13 in this paper. Therefore, for the Malaysian labour market, the wage curve function is:

$$
\ln W R_{\text {flab }}=-0.13 \ln U E R_{\text {flab }}
$$

Where $\ln W R_{\text {flab }}$ is the actual wage for various labour skills, and $l n U E R_{\text {flab }}$ is the unemployment rate.

$$
W R_{\text {flab }}=U E R_{\text {flab }}^{-0.13}
$$

By definition, the real wage $\left(W R_{\text {flab }}\right)$ is the nominal wage based on the consumer price index (CPI):

$$
\begin{aligned}
& W R_{\text {flab }}=W F_{\text {flab }} / C P I \\
& W F_{\text {flab }} / C P I=U E R_{\text {flab }}^{-0.13}
\end{aligned}
$$

Thus, it can be rewritten as:

Before equation (14) does not contain the assumption of a benchmarking equilibrium with a relative price of labour and consumption bundle equal to one. We change this equation to achieve benchmarking accuracy. It should be called the initial unemployment rate. Also, benchmark labour prices and business indices have unity to be considered (Kuster et al., 2007). The equation then introduces a scaling parameter (equation 14), which gives the following equation:

$$
\frac{W F_{f l a b}}{C P I}=\frac{\frac{W{ }^{0} 0_{f l a b}}{C P I 0}}{U E R 0_{f l a b}^{0.13}} \cdot U E R_{f l a b}^{-0.13}
$$

$U E R 0_{\text {flab }}$ is the initial unemployment rate, while $U E R_{\text {flab }}$ is the unemployment rate endogenously. Both $W F 0_{f l a}$ and CPIO are unity and calculated from the benchmark data, Malaysian SAM 2010. Equation (14) and (15) are used in this study.

\subsection{Data and Calibration}

\section{Step 2: Construction of benchmark dataset}

We developed a SAM table using the 2010 IO table, the base year for simulations. The SAM is derived from the 2010 Malaysian input-output table, complemented by the Malaysian National Account obtained from the Malaysian Department of Statistics (DOSM).

The model consisted of four agents: local households, immigrants, producers, and the government. Although the 
maximizing actions described the first three, government decisions were exogenous. Local households are divided into four types of skills: low-skilled, semiskilled, skilled, and high skilled.

The model consisted of twelve industries, twelve composite commodities, five factors of production factors (including four groups of skills level and capital), three domestic institutions (including households, enterprise, and government), a savings-investment account, and a rest of the world account, based on the Malaysian Social Accounting Matrix (SAM). Total employment data is derived from the 2010 LFS, the same survey for which salaries were eligible. Since the model, especially its labour market, has been applied to Malaysia, it has been emphasized.

In each industry, the total value added is from the 2010 IO table. Wage-related data came from the LFS. Every sector's wage bills from the 2010 LFS multiply the average wages by skill and industry with the number of employees of that skill and industry (the difference between these and the original wage bill is capital remuneration). Thus, mean wages and wage earners are following the LFS in all sectors.

From the 2010 Input-Output (IO) table, investment by origin was taken and divided into destination sectors. For this exercise, details from a study entitled 'National Accounts Capital Stock Statistics' by DOSM proved quite useful. Since the data represented higher aggregation than that used for the calculation, we presumed that our sub-sectors were equally distributed by expenditure.

Using production and LFS data from 2010 through 2016, we calibrated the model's key parameters through an iterative process. This exercise's outcome was that the reference scenario was appropriately in line with the LFS figures and the evolution of the main variables at the macro and sectoral levels.

\section{Step 3: Determine exogenous elasticities and calibration.}

To quantitatively evaluate the overall effect of immigration on labour market outcomes (wages and unemployment rates) for local workers of all skill classes, we calibrated the model based on Malaysian economic data. Initial values of endogenous variables and exogenous parameters were used in the model parameters. Nine parameters in the production block were completely characterized by our model economy. A summary of our calibration is given in Table 1.

Table 1. Parameterization of the Model

\begin{tabular}{ll}
\hline \multicolumn{2}{l}{ Jointly calibrated to match } \\
\hline $\begin{array}{l}\sigma^{\mathrm{a}}=6 \\
\sigma^{\mathrm{a}}=0.3\end{array}$ & $\begin{array}{l}\text { The elasticity of output aggregated } \\
\text { the elasticity of substitution (Aggregated factor and intermediates) }\end{array}$ \\
\hline Differ by industry* & the elasticity of substitution (Aggregated Labour and Capital) \\
\hline$\sigma^{\mathrm{va}}=0.3-1.2$ & the elasticity of substitution (Aggregated higher and lower-skilled) \\
$\sigma^{\text {lab }}=0.6-1.3$ & the elasticity of substitution (Aggregated high skilled and skilled) \\
$\sigma^{\text {lsk }}=1.1-1.7$ & the elasticity of substitution (Aggregated semiskilled and low-skilled) \\
$\sigma^{\text {lusk }}=0.7-1.9$ &
\end{tabular}

*see appendix 2

Source: Allan et al. (2007), Ahmed \& O'Donoghue (2010), Pouliakas et al. (2008), Barnes et al., (2008), Pauw (2002), Chirinko et al. (2004), Bednarikov \& Doucha (2009), and author's calculations

SAM provided values, among others, for output and consumption, exports, and imports. We were provided with details on immigrant's and residents' wages and employment status through Labor Force Surveys. Using initial values obtained from these sources, specific indiscernible parameters could be determined. Others, like substitution elasticity, had to be measured. We decided to approximate these elasticities where possible; otherwise, appropriate values from the literature were used.

The key focus of the immigration debates was on the elasticity of replacement between workers from different skill groups and the impact on relative salaries as immigration shifts the relative abundance of different skill types of labour. However, we believed that substitution elasticity was infinite in this analysis. Krussel et al. (2000) and Johnson (1997) found comparable range elasticity of substitution between low-skilled and skilled labour to be approximately 1.5 and 1.67, respectively. Meanwhile, Freeman (1982) claimed that substitution elasticity varies from 1.0 to 2.0.0 between talented and less talented. The choice of elasticity is consistent with the inference that the higher the industry's technical level, the more difficult it is for various labor types to be substituted. The lower the value of elasticity. This study set the elasticity between higher and lower aggregated labour is around 0.6 until 1.3 and high skilled and skilled labour approximately 1.3 until 1.49 and between semiskilled and low-skilled approximately 0.7 until 1.9. 


\section{Results}

The model calibrated to Malaysia's data to assess quantitatively the overall impact of immigration on labour market outcomes (wages and unemployment rates). The effect of immigration on the Malaysian economy was obtained through several simulations with different scenarios.

\section{Step 4: Simulation}

Table 2 represents the simulated scenarios were first categorized into three classes: A, B, and C. Under each class were four subclasses, each denoting a distinct skill level. Scenarios in Class A assumed that an immigrant's inflow in certain skill levels into the Malaysian labour market would increase the labour supply with the corresponding skill levels by 1 percent. Simulation by a 1 percent increase in the labour supply selected based on Boeri and Brucker (2005) model.

The simulation represents a small scale increasing in the labour market supply. The subclasses under it, A1, A2, A3, and A4, supposed that the increase was restricted only in the labour supply of specific skills, either high skilled (managers and professionals), skilled (technicians and associate professionals), semiskilled (clerical and support workers, services and sales workers, skilled agriculture, forestry, and fishery workers, and craft and related machines-operators and assemblers), or low-skilled (elementary workers). Class B and its subclasses followed similar assumptions, except that the labour supply was expected to increase by 10 percent for each skill level. Following the Boeri and Brucker (2005) model, the 10 percent increase in the labour supply represents a large scale. Class $\mathrm{C}$ and its subclasses assumed that an immigrant's inflow would decrease the national labour stock for each skill level by 1 percent. The only small-scale decreasing is about 1 percent selected for simulation. The large-scale decreasing number of inflows immigrants rarely happen in developing and developed countries.

Table 2. Definitions for simulation scenarios

\begin{tabular}{ll}
\hline Scenario & Explanation \\
\hline Class A & The inflow of immigrant increases the national labour supply by $1 \%$ \\
A1 & The inflow of high skilled immigrant increases the national supply of highly skilled labour by $1 \%$ \\
A2 & The inflow of skilled immigrant increases the national supply of skilled labour by $1 \%$ \\
A3 & The inflow of semiskilled immigrant increases the national supply of semiskilled labour by $1 \%$ \\
A 4 & The inflow of low-skilled immigrant increases the national supply of low-skilled labour by $1 \%$ \\
A5 & The inflow of all types of immigrant increases the national supply of all types of labour by $10 \%$ \\
Class B & The inflow of immigrant increases the national labour supply by $10 \%$ \\
B1 & The inflow of high immigrant worker increases the national supply of high skilled labour by $10 \%$ \\
B2 & The inflow of skilled immigrant increases the national supply of skilled labour by $10 \%$ \\
B3 & The inflow of semiskilled immigrant increases the national supply of semiskilled labour by $10 \%$ \\
B4 & The inflow of low-skilled immigrant increases the national supply of low-skilled labour by $10 \%$ \\
B5 & The inflow of all types of immigrant increases the national supply of all types of labour by $10 \%$ \\
Class C & The inflow of immigrant decreases the national labour supply by $1 \%$ \\
C1 & The inflow of high skilled immigrant decreases the national supply of high skilled labour by $1 \%$ \\
C2 & The inflow of skilled immigrant decreases the national supply of skilled labour by $1 \%$ \\
C3 & The inflow of semiskilled immigrant decreases the national supply of semiskilled labour by $1 \%$ \\
C4 & The inflow of low-skilled immigrant decreases the national supply of low-skilled labour by $1 \%$ \\
C5 & The inflow of all types of immigrant decreases the national supply of all types of labour by $1 \%$ \\
\hline
\end{tabular}

Increasing labour supplies would directly stimulate competition for job-seekers, leading to a decline in wages and an increase in that particular skill group's unemployment rates. The economics theory commonly predicts that immigration to developing countries or a small scale is expected to reduce benefits to workers group that have substitutes skilled while increasing returns to complementary factors. Table 3 to table 7 shows the results based on the scenarios above.

\section{Wages}

Percentage change on wages effects from the simulated of a $1 \%$ increasing in the supply of national labour. A $1 \%$ increase in high skilled labour immigration to Malaysia will decrease the national incomes of high skilled employees by $0.807 \%$ and $0.214 \%$. On the other hand, increased percentages by $0.01 \%$ and $0.23 \%$ for semiskilled and low-skilled labour. These results indicate that job competition in the local labour market. 
Competition happens between the high skilled and skilled groups, and there were complementary consequences between the higher-skilled and lower-skilled groups. In Scenario A2, an increasing supply of high skilled and skilled labour workers affected by the rising numbers of migrants was shown to be $0.126 \%$ and $0.74 \%$ and to increase the wages of semiskilled and low-skilled labour by $0.051 \%$ and $0.172 \%$.

Scenario A3 reveals that semiskilled immigrant workers only harmed local semiskilled workers and positively impacted all other types of workers' wages. Scenario A4 showed a positive wage effect at 0.06 percent for high-skilled and skilled employees, with unfavorable results at 0.062 percent and -0.607 percent for semiskilled and low-skilled employees. Scenario A5 gives an overall image of the effect of all forms of immigration on the local labour market. It showed that immigration had a more significant negative impact than lower-skilled labour on higher-skilled labour incomes.

Table 3. Impacts of increasing labour supply quantity on total wages (+1\%)

\begin{tabular}{ccccccc}
\hline & & \multicolumn{4}{c}{ Scenarios' results $(\Delta \%)$} \\
\cline { 3 - 7 } & & A1 & A2 & A3 & A4 & A5 \\
\hline \multirow{2}{*}{ Higher- Skilled } & High skilled & -0.807 & -0.126 & 0.053 & 0.061 & -0.869 \\
& Skilled & -0.214 & -0.74 & 0.0504 & 0.062 & -0.89 \\
\multirow{2}{*}{ Lower- Skilled } & Semiskilled & 0.057 & 0.051 & -0.614 & -0.062 & -0.618 \\
& Low skilled & 0.279 & 0.172 & 0.007 & -0.607 & -0.258 \\
\hline
\end{tabular}

The findings provide crucial insight and space to change policy: firstly, high skilled or professional immigrant labour entry weakens the wage disparity between various employment types. Secondly, the growth of lower-skilled workers would increase the higher-skilled workforce's wages but depreciate the lower-skilled workforce's wages, which may add to the social wage gap.

Table 4. Impacts of increasing labour supply quantity on total wages $(+10 \%)$

\begin{tabular}{ccccccc}
\hline & & \multicolumn{4}{c}{ Scenarios' results $(\Delta \%)$} \\
\cline { 3 - 7 } & & B1 & B2 & B3 & B4 & B5 \\
\hline \multirow{2}{*}{ Higher- Skilled } & High skilled & -6.95 & -0.752 & 0.075 & 0.149 & -7.403 \\
& Skilled & -1.563 & -6.266 & 0.054 & 0.152 & -7.512 \\
\multirow{2}{*}{ Lower- Skilled } & Semiskilled & 0.12 & 0.064 & -4.888 & -0.152 & -4.995 \\
& Low skilled & 2.231 & 1.198 & 0.099 & -4.918 & -2.263 \\
\hline
\end{tabular}

The simulated results for Scenario B, a large-scale rise in labour supply, are summarised in Table 4 above. The results of Scenario B1 showed that when the local high skilled labour supply rose by 10 percent, the wages of high skilled labour would drop dramatically by 6.95 percent. The findings also showed that a wage rise of $2.23 \%$ would be enjoyed by low-skilled labour. Scenarios B2, B3, and B4 contributed to a $6.27 \%, 4.89 \%$, and $4.86 \%$ decline in skilled, semiskilled, and low-skilled labour wages. In the final scenario, all labour groups would see their wages falling; the least affected of the four groups would be low-skilled labour.

Table 5 presents class $\mathrm{C}$ results, which measured how a decrease in immigrant labour supply could affect total wages. The results revealed a pattern contradictory to the first two scenarios. Where wages increased in the first two scenarios, they would decrease in this scenario, and vice versa.

Table 5. Impacts of decreasing labour supply quantity on total wages (-1\%)

\begin{tabular}{ccccccc}
\hline & & \multicolumn{4}{c}{ Scenarios' results $(\Delta \%)$} \\
\cline { 3 - 7 } & & $\mathrm{C} 1$ & $\mathrm{C} 2$ & $\mathrm{C} 3$ & $\mathrm{C} 4$ & $\mathrm{C} 5$ \\
\hline \multirow{2}{*}{ Higher- Skilled } & High skilled & 0.825 & 0.825 & -0.053 & -0.061 & 0.789 \\
& Skilled & 0.217 & 0.217 & 0.05 & -0.062 & 0.913 \\
\multirow{2}{*}{ Lower- Skilled } & Semiskilled & -0.057 & -0.051 & 0.635 & 0.062 & 0.637 \\
& Low skilled & -0.263 & -0.173 & -0.057 & 0.625 & 0.255 \\
\hline
\end{tabular}

In the US national labour market, Borjas (2003) was the first to correlate salaries and immigration through capability classes. In the case of France, Edo (2015) shows that immigration has no detrimental effect on the wages of similarly educated local workers. This implies that the composition of the French wage appears to be rigid. Another series of skill-cell research, for example, Breunig et al. (2017) for Australia, found no negative 
effect of immigration on the incomes of competing local workers. The study showed that the distribution of migrants plays an important role in assessing the detrimental or non-detrimental effects on wage rates. The weakness of the wage level competing for skills is the large scale of immigration.

\section{Unemployment Rate}

This section showed the effect of rising the local labour supply on the unemployment rate of the various forms of incoming immigrant labour. The findings in the A1 scenario in Table 6 below show that $1 \%$ higher supplies of highly skilled workers would raise the unemployment rate for high skilled workers by $5.839 \%$ and $1.1 \%$. However, the unemployment rate has dropped by $0.325 \%$ for semiskilled employees and $1.65 \%$ for low-skilled workers. A higher supply of high skilled labour will generate more competition within the group's labor market and, consequently, raise its unemployment rate. In scenario A2, identical findings were also evinced. Meanwhile, scenarios A3, were the opposite of the first two scenarios; the lower-skilled group would face higher unemployment rates. In the final scenario, unemployment rates would escalate across all labour groups.

The diagonal matrix line indicates that an increase in supply in each skill type of labour migrant would reinforce competition within that particular skill labour group. The most important insight gained from the above study was that high skilled immigrant labour has a significant positive influence on Malaysia's labor market. As Table 6 indicates, high skilled immigrant labour lowered the overall unemployment rate by $0.24 \%$, while other skill classes exacerbated it. A clear policy implication came about from this salient point: that within the Malaysian economic structure, the lack of a high skilled labour force enables it to have superior marginal profit, relative to other skill groups.

Table 6. Impacts of increasing labour supply quantity on the unemployment rate $(+1 \%)$

\begin{tabular}{ccccccc}
\hline \multirow{2}{*}{ Higher- Skilled } & \multicolumn{5}{c}{ Scenarios' results $(\Delta \%)$} \\
\cline { 3 - 7 } & High skilled & A1 & A2 & A3 & A4 & A5 \\
\hline \multirow{2}{*}{ Lower- Skilled } & Skilled & 1.0939 & 0.53 & -0.098 & -0.059 & 6.074 \\
& Semiskilled & -0.325 & -0.165 & 4.364 & 0.116 & 4.035 \\
& Low skilled & -1.645 & -0.986 & -0.226 & 4.418 & 1.187 \\
\hline
\end{tabular}

Class B scenarios present results on the variation of the unemployment rate. The findings show that a 10 percent rise in the labour market would significantly increase labor unemployment's relative rate. The unemployment rate for high skilled and skilled workers rose by 69 percent and 62 percent, respectively, as seen in scenarios B1 and B2. On the other hand, adverse effects for scenarios B3 and B4 showed a lower marginal increase in the unemployment rate, with $44.9 \%$ for semiskilled and $46.55 \%$ for unskilled.

Table 7. Impacts of increasing labour supply quantity on the unemployment rate $(+10 \%)$

\begin{tabular}{ccccccc}
\hline & & \multicolumn{4}{c}{ Scenarios' results $(\Delta \%)$} \\
\cline { 3 - 7 } & & B1 & B2 & B3 & B4 & B5 \\
\hline \multirow{2}{*}{ Higher- Skilled } & High skilled & 68.93 & 4.59 & -1.33 & -1 & 72.34 \\
& Skilled & 10.19 & 62.28 & -1.17 & -1.03 & 73.92 \\
\multirow{2}{*}{ Lower- Skilled } & Semiskilled & -2.62 & -1.13 & 44.89 & 0.64 & 41.49 \\
& Low skilled & -17.08 & -9.35 & -1.52 & 46.55 & 13.79 \\
\hline
\end{tabular}

It is also interesting to observe the relationship between unemployment and increasing labour immigration. Figure 2 shows how the labour immigration by four different skilled labour types at differing supply rates affects change the unemployment rate. Recently, Lozej (2018) found that migration impact using search-and-matching framework indicate that unemployment increases immediately after the immigration shock. Aslan, A., and Altinöz, B. (2020) there is a positive effect of immigration to the United States on the unemployment rate to in the long run. In other words, an increase in the immigrant population increases the unemployment rate by 0.14 percent.

The results fromthis studies are summarised below:

(1) Only the high skilled immigration labour group could lower unemployment rates;

(2) As the high skilled immigration labour supply rate increased, the unemployment rate continuously fell before reaching its peak at $4 \%$. The marginal effect continued to lower until the optimal point of $8 \%$, signifying the high 
skilled labour inflow's upper limit.

(3) The decline in the national unemployment rate was not influenced by the other three groups. Surprisingly, the low-skilled immigration labour category had a smaller negative impact than semiskilled immigration workers. Within the semiskilled group, each percent rise in the national supply of labour caused unemployment to grow twice as fast as the low-skilled group.

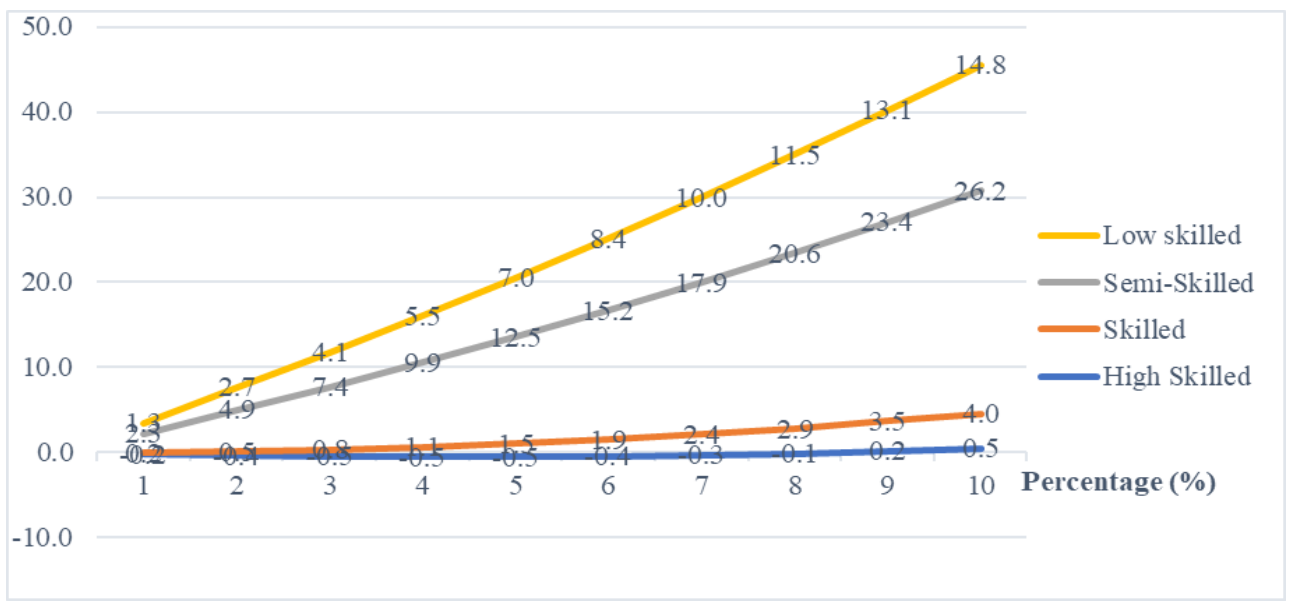

Figure 2. The effect of various types of immigrant skills on the unemployment rate (\%)

From the above findings, the Malaysian labour market's current situation is should be concentrated on high skilled migrant labour and low-skilled migrant labour rather than semiskilled migrant labour. Malaysia has strong economic growth and an advanced industrial structure, which employs labour of various skill groups. The analysis also indicates that a small rise in high skilled immigrant labour will reduce the unemployment rate; likewise, increasing more than 4 percent will increase the unemployment rate. This analysis from the general equilibrium approach.

\subsection{Sensitivity Analysis}

This study tests the sensitivity analysis to check whether substitutions' elasticities elasticity assumes four-level CES production functions. Li and Rose (1995) 100 simulations were conducted to verify that the main aggregate variables of the experiment's means were identical to those obtained from the point estimates. We are applying an elasticities generator in GAMS. We set $-95 \%$ and $+95 \%$ lower and upper boundaries, respectively. In a more spectrum of elasticity value, the sensitivity analysis can increase the performance's robustness. In GAMS, the random number generating a programme is provided as follows: Eseed $=1+$ gmilisec (jnow); Prdelas1 $(\mathrm{A})=$ form $(0.1,1.5)$; Prdelas2 $(\mathrm{A})=$ form $(0.1,0.5)$; Prdelas3 $(\mathrm{A})=$ form $(0.3,2.5)$; Prdelas4 $(\mathrm{A})=$ form $(0.5,3)$; Prdelas5 $(\mathrm{A})=$ form $(0.3,3)$;

Where the random number of seeds is generated by 'Eseed'; 'gmilisec' can be zero, so that plus one is valid for 'Eseed'; 'jnow' is the current time, which guarantees the elasticity of each random variance in a given range; Prodelas1 is the capital and total labour elasticity, Prdelas2 is the aggregate input and value-added elasticity, Prdelas 3 is the higher-skilled aggregate labour, and lower-skilled aggregate labour elasticity, The high skilled labour, and skilled labour elasticity are Prdelas4, and semiskilled labour and low-skilled labour elasticity is Prodelas5. For the sensitivity study, the economic indicator, the Unemployment Rate (UER), was selected.

Table 8. sensitivity test on UER elasticity

\begin{tabular}{lllllllllll}
\hline & A1 & A2 & A3 & A4 & A5 & B1 & B2 & B3 & B4 & B5 \\
\hline New Result (Average) & -0.24 & 0.16 & 0.40 & 1.24 & 3.59 & 0.55 & 0.31 & 26.20 & 14.72 & 42.19 \\
Standard Deviation & 0.11 & 0.17 & 0.13 & 0.08 & 0.49 & 1.24 & 0.97 & 1.22 & 1.02 & 6.30 \\
95\% confidence interval (Lower) & -0.32 & 0.15 & 2.33 & 1.28 & 3.47 & -0.29 & 3.67 & 25.64 & 14.45 & 39.34 \\
95\% confidence interval (Upper) & 0.06 & 0.33 & 2.48 & 1.36 & 4.11 & 2.90 & 5.43 & 27.31 & 15.26 & 46.21 \\
Initial Result & -0.24 & 0.16 & 2.33 & 1.25 & 3.60 & 0.50 & 4.05 & 26.22 & 14.76 & 40.20 \\
\hline
\end{tabular}

The statistics for random Ran 100 simulations are provided in Table 8. Most of the unemployment rate's initial results were identical to the average values derived from the different elasticity simulations and located within 
the $95 \%$ confidence interval's upper and lower limits. As was the case in A3 (2.33 percent) relative to the average value ( 0.4 percent), the initial outcome of the unemployment rate in B2 (4.05 percent) was very different from the average value ( 0.31 percent). In summary, the Comprehensive Sensitivity Analysis test's findings have shown that nearly all the variables measured using this research were highly robust and interpreted the truth carefully.

\section{Discussion}

Nonetheless, the presence of migrant workers in the Malaysian economy remains necessary. Their employment in the early decades of economic development, especially during labour shortages, has enabled the country to stand tall over most of its ASEAN peers. Even now, they remain a necessity for certain sectors and occupations where there is no or little local supply. Similarly, most Malaysian researchers support the necessity of migrant worker, but they advise their proper regulation (Docquier, Ozden, \& Peri, 2014). The government has also maintained this stance, as reflected in Malaysia Plan and the Construction Industry Transformation Programme (CITP), among others. Both recommend the proper management of migrant worker inflow and employment. Poor regulation would result in overdependence, much like the case in agriculture, specifically oil palm. As the number of Indonesian workers declined, preferring to work in their own country, the productivity of the industry has suffered (Ismail \& Zin, 2003).

Clearly, in Malaysia situation present that is increasing immigration labour had direct effects. Both high skilled and skilled immigrant labour had negatively affected wages, while the opposite effect for semiskilled and low-skilled labour. On the other hand, the impact on wages and semiskilled immigration labour negatively affected its skill group. In contrast, low-skilled immigration labour reduced the national wages for both semiskilled and low-skilled labour.

Using the wage curve theory, there was an opposite correlation to immigration's impact on the unemployment rate. The results demonstrated that migrants' skills would encourage competitiveness in the labour market, reduced salaries, and increase relative unemployment. Contrary to that, the wages of complementary labour have been positively correlated. The study indicates that the overall unemployment rate can only be decreased by a slight rise in high skilled migrant workers. In contrast, large-scale immigration labour would have the opposite results. The study showed that the distribution of migrants plays an important role in assessing the detrimental or non-detrimental effects on wage and unemployment level.

\section{Conclusion}

The present paper has extended the IFPRI standard CGE approach in analyzing the effect of immigration on wages, in the tradition of Borjas (2003), Borjas and Katz (2007), and Ottaviano and Peri (2006).

They were using a nested-CES framework to understand immigration's impact on total wage and unemployment. The framework imposes restrictions on cross-elasticities. It is sufficiently flexible to allow different nesting structures to be permitted, thus testing alternative restrictions. The replacement elasticity of higher-skilled and lower-skilled labor ( $\sigma \mathrm{lab})$ ranged from 0.6 to 1.3 . While ( $\sigma \mathrm{lsk})$ stayed at around 1.5 , the substitution elasticity between high skilled and skilled labour is reflected. The elasticity of substitution between semiskilled and low-skilled labour ( $\sigma$ lusk) ranged from 0.7 to 1.9 . A small but significant degree of imperfect substitutability among locals and immigrants within skill groups was found in this context.

In conclusion, the importation of migrant workers required to manage properly. The results revealed that the increase in lower-skilled migrant workers would raise the wages of the higher-skilled group but depress the wages of the lower-skilled group. This situation could widen the social wage gap. The results also found that only a small increase in high skilled migrant workers could reduce the total unemployment rate. At a larger scale, they would increase total unemployment.

\section{References}

Abdul Aziz, A. R. (2001). Bangladeshi migrant workers in Malaysia's construction sector. Asia Pacific Population Journal, 16(1), 3-22.

Ahmed, V., \& O'Donoghue, C. (2010). Global economic crisis and poverty in Pakistan. International Journal of Microsimulation, 3(1), 127-129.

Aslan, A., \& Altinöz, B. (2020). The relationship between unemployment and immigration with linear and nonlinear causality tests: Evidence from the United States. Economic Journal of Emerging Markets, 12(1), 13-24. https://doi.org/10.20885/ejem.vol12.iss1.art2

Baas, T., \& Brücker, H. (2008). Macroeconomic consequences of migration diversion: A CGE simulation for 
Germany and the UK (No. 3/2008). IAB-Discussion Paper. Retrieved from http://hdl.handle.net/10419/32728

Blanchflower, D. G., \& Oswald, A. J. (1995). An introduction to the wage curve. Journal of Economic Perspectives, 9(3), 153-167. https://doi.org/10.1257/jep.9.3.153

Borjas, G. J. (2003). The labor demand curve is downward sloping: Reexamining the impact of immigration on the labor market. The Quarterly Journal of Economics, 118(4), 1335-1374. https://doi.org/10.7208/chicago/9780226066684.003.0002

Borjas, G. J. (2014). Immigration economics. Harvard University Press. https://doi.org/10.4159/harvard.9780674369900

Borjas, G. J., \& Katz, L. F. (2007, May). The evolution of the Mexican-born workforce in the United States. In Mexican immigration to the United States (pp. 13-56). University of Chicago Press. https://doi.org/10.7208/chicago/9780226066684.003.0002

Borjas, G. J., Freeman, R. B., Katz, L. F., DiNardo, J., \& Abowd, J. M. (1997). How much do immigration and trade affect labor market outcomes. Brookings papers on economic activity, 1997(1), 1-90. https://doi.org/10.2307/2534701

Breunig, R., Deutscher, N., \& To, H. T. (2017). The relationship between immigration to Australia and the labour market outcomes of Australian-born workers. Economic Record, 93(301), 255-276. https://doi.org/10.1111/1475-4932.12328

Brücker, H., \& Kohlhaas, M. (2004). International migration to Germany: A CGE analysis of Labour Market Impact. conference Paper. In 7th Annual Conference on Global Economic Analysis, Washington, DC.

Card, D. (2009). Immigration and inequality. American Economic Review, 99(2), 1-21. https://doi.org/10.1257/aer.99.2.1

Chirinko, R. S., Haan, L. J., \& Sterken, E. (2004). Asset price shocks, real expenditures, and financial structure: A multi-country analysis. University of Groningen.

Cockburn, J., Fofana, I., Decaluwe, B., Mabugu, R., \& Chitiga, M. (2007). A gender-focused macro-micro analysis of the poverty impacts of trade liberalization in South Africa. In Equity (pp. 269-305). Emerald Group Publishing Limited. https://doi.org/10.1016/S1049-2585(07)15011-0

Davies, R., \& Ratts $\varnothing$, J. (2000). Zimbabwe: Economic adjustment, income distribution and trade liberalization. Center for Economic Policy Analysis Working Paper Series, 1. https://doi.org/10.1093/acprof:oso/9780195145465.003.0011

Del Boca, D., \& Venturini, A. (2005). Italian migration. European migration: What do we know, 303-336.

Devadason, E. S., \& Meng, C. W. (2014). Policies and laws regulating migrant workers in Malaysia: A critical appraisal. Journal of Contemporary Asia, 44(1), 19-35. https://doi.org/10.1080/00472336.2013.826420

Diaz, C. J., \& Ore, P. D. (2020). Landscapes of appropriation and assimilation: The impact of immigrant-origin populations on US cuisine. Journal of Ethnic and Migration Studies, 1-25. https://doi.org/10.1080/1369183X.2020.1811653

Docquier, F., Ozden, Ç., \& Peri, G. (2014). The labour market effects of immigration and emigration in OECD countries. The Economic Journal, 124(579), 1106-1145. https://doi.org/10.1111/ecoj.12077

Edo, A. (2019). The impact of immigration on the labor market. Journal of Economic Surveys, 33(3), 922-948. https://doi.org/10.1111/joes.12300

Carneiro, F. G., \& Abbache, J. S. (2003). The impacts of trade on the Brazilian labour market: A CGE model approach. World Development, 1581-1595.

Facchini, G., \& Mayda, A. M. (2009). Does the welfare state affect individual attitudes toward immigrants? Evidence across countries. The review of economics and statistics, 91(2), 295-314. https://doi.org/10.1162/rest.91.2.295

Freeman, R. B., \& Medoff, J. L. (1982). Substitution Between Production Labor and Other Inputs in Unionzed and Nonunionized Manufacturing. The Review of Economics and Statistics, 220-233. https://doi.org/10.2307/1924301

Hosoe, N., Gasawa, K., \& Hashimoto, H. (2010). Textbook of computable general equilibrium modeling: Programming and simulations. Springer. 
Ismail, R., \& Zin, R. H. M. (2003). Earnings differentials determinants between skills in the Malaysian manufacturing sector. Asian Economic Journal, 17(4), 325-340.

Johnson, G. E. (1997). Changes in earnings inequality: The role of demand shifts. Journal of economic perspectives, 11(2), 41-54. https://doi.org/10.1257/jep.11.2.41

Kanapathy, V. (2004). International migration and labour market developments in Asia: Economic recovery. The labour market and migrant workers in Malaysia, paper presented at the 2004 Workshop on International Migration and Labour Markets in Asia, Tokyo, Japan, February 5-6.

Kaur, A. (2008). International migration and governance in Malaysia: Policy and performance. UNEAC Asia Papers, 22, 4-18.

Krusell, P., Ohanian, L. E., RosRull, J. V., \& Violante, G. L. (2000). Capital-skill complementarity and inequality: A macroeconomic analysis. Econometrica, 68(5), 1029-1053. https://doi.org/10.1111/1468-0262.00150

Küster, R., Ellersdorfer, I. R., \& Fahl, U. (2007). A CGE-analysis of energy policies considering labor market imperfections and technology specifications. https://doi.org/10.2139/ssrn.960725

Lewer, J. J., \& Van den Berg, H. (2008). A gravity model of immigration. Economics letters, 99(1), 164-167. https://doi.org/10.1016/j.econlet.2007.06.019

Lisenkova, K., McGregor, P., Pappas, N., Swales, J. K., Turner, K., \& Wright, R. E. (2008). The Macroeconomic Impacts of Demographic Change in Scotland: Evidence from a Computable General Equilibrium Model. Strathclyde: University of Strathclyde.

Lofgren, H., Harris, R. L., \& Robinson, S. (2002). A standard computable general equilibrium (CGE) model in GAMS (Vol. 5). Intl Food Policy Res Inst.

Lozej, M. (2019). Economic migration and business cycles in a small open economy with matching frictions. Economic Modelling, 81, 604-620. https://doi.org/10.1016/j.econmod.2018.07.012

Mantra, I. (2000). Indonesian labour mobility to Malaysia (A Case Study: East Flores, west Lombok and the island of Bawean). In Labour Migration in Indonesia: Policies and practice (pp. 143-184). Population Studies Center Gadjah Mada University, Yogyakarta.

Ottaviano, G. I., \& Peri, G. (2012). Rethinking the effect of immigration on wages. Journal of the European economic association, 10(1), 152-197. https://doi.org/10.1111/j.1542-4774.2011.01052.x

Pauw, K., \& Edwards, L. (2006). Evaluating the general equilibrium effects of a wage subsidy scheme for South $\begin{array}{lllll}\text { Africa. South African Journal of Economics, } & \text { 74(3), 442-462. }\end{array}$ https://doi.org/10.1111/j.1813-6982.2006.00082.x

Pouliakas, K., Roberts, D., Balamou, E., \& Psaltopoulos, D. (2009). Modelling the effects of immigration on regional economic performance and the wage distribution: A CGE analysis of three EU regions.

McNabb, R., \& Said, R. (2013). Trade openness and wage inequality: Evidence for Malaysia. The Journal of Development Studies, 49(8), 1118-1132. https://doi.org/10.1080/00220388.2013.794263

Sharpe, J., \& Bollinger, C. R. (2020). Who competes with whom? Using occupation characteristics to estimate the impact of immigration on native wages. Labour Economics, 66, 101902. https://doi.org/10.1016/j.labeco.2020.101902

Sultana, N. (2007). National Identity, Mode of Networking and Integration of Bangladeshi Community in a Multi-cultural Society: Migrant Bangladeshis in Peninsular Malaysia. Akademika, 70(1).

Ullah, A. A., \& Panday, P. K. (2007). Remitting money to Bangladesh: What do migrants prefer? Asian and Pacific Migration Journal, 16(1), 121-137. https://doi.org/10.1177/011719680701600106

$\mathrm{Wu}, \mathrm{Y}$. (2011). Economic impacts of different skilled levels of immigration labour: A CGE assessment for the UK (Doctoral dissertation, Middlesex University). Retrieved from https://eprints.mdx.ac.uk/12380/

\section{Copyrights}

Copyright for this article is retained by the author(s), with first publication rights granted to the journal.

This is an open-access article distributed under the terms and conditions of the Creative Commons Attribution license (http://creativecommons.org/licenses/by/4.0/). 


\section{Appendix A}

\section{Four-level production activities structure}

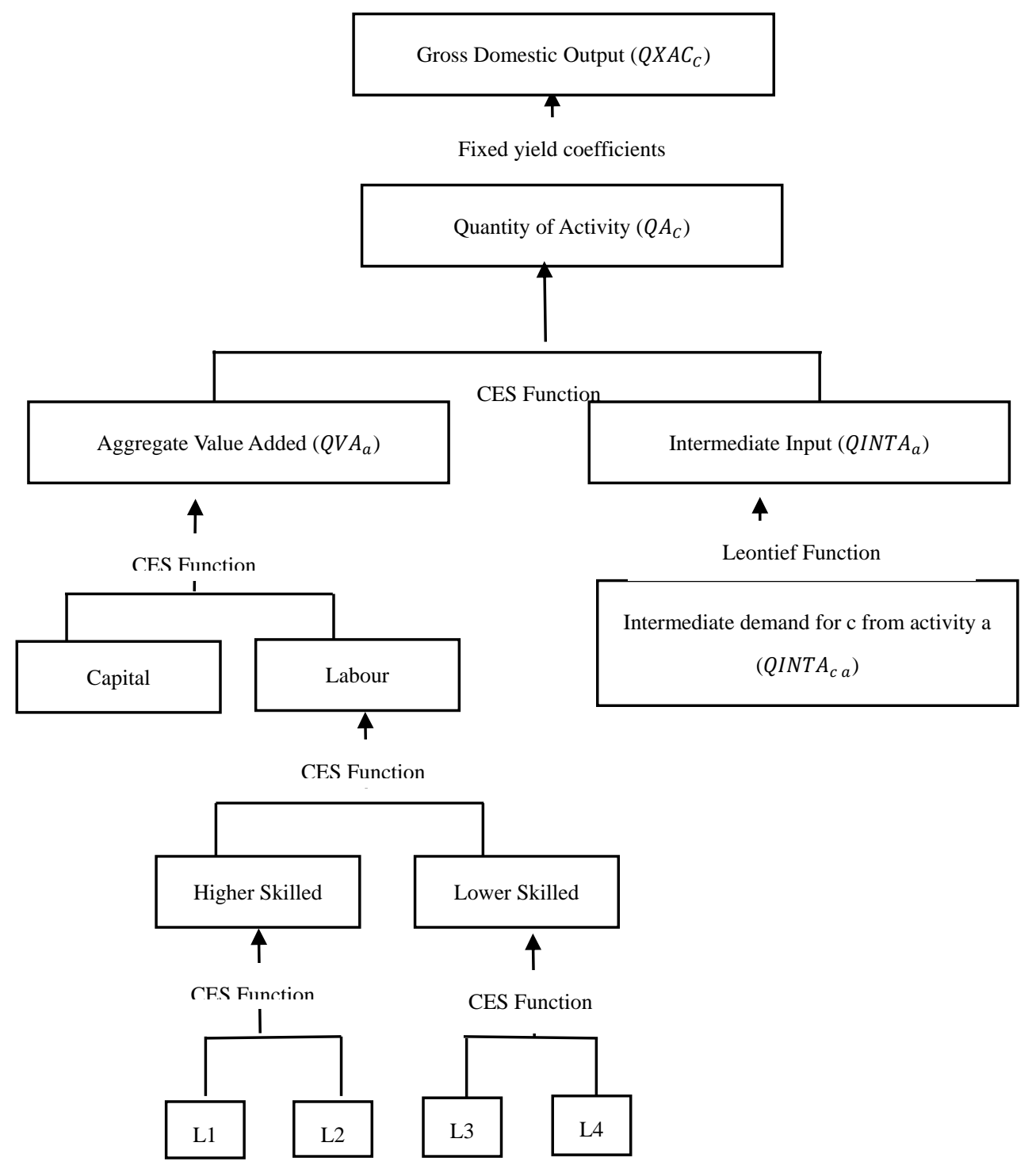




\section{Appendix B}

\section{Selected elasticities of different industries}

\begin{tabular}{cccccccc}
\hline Sector & $\sigma^{\mathrm{va}}$ & $\sigma^{\mathrm{lab}}$ & $\sigma^{\mathrm{lsk}}$ & $\sigma^{\mathrm{lusk}}$ & $\sigma^{\mathrm{q}}$ & $\sigma^{\mathrm{t}}$ & $\mathrm{y}^{\mathrm{m}}$ \\
\hline Agriculture & 0.5 & 1.3 & 1.2 & 1.7 & 1.4 & 2 & 0.4 \\
Mining \& Quarrying & 0.3 & 1.1 & 1.5 & 1.5 & 1.3 & 2 & 1.2 \\
Manufacturing & 0.4 & 1.1 & 1.3 & 1.9 & 1.3 & 2 & 1.2 \\
Electricity, Gas \& Water & 1.2 & 0.6 & 1.3 & 1.7 & 2 & 2 & 1.1 \\
Construction & 0.7 & 1.1 & 1.2 & 1.9 & 2 & 2 & 1.2 \\
Wholesale \& Retail Trade & & & & & 2 & 2 & 1.2 \\
Hotel \& Restaurants & & & & & 2 & 2 & 1.2 \\
Transport \& Communication & 0.3 & 1.1 & 1.5 & 1.5 & 2 & 2 & 1.2 \\
Finance \& Insurance & 0.6 & 0.7 & 1.5 & 0.6 & 2 & 2 & 1.2 \\
Real Estate \& Ownership of Dwellings & 0.4 & 0.7 & 1.5 & 1.5 & 2 & 2 & 1.2 \\
Business \& Private Services & 0.4 & 0.7 & 1.5 & 1.5 & 2 & 2 & 1.2 \\
Other Services & 0.8 & 0.9 & 1.7 & 0.9 & 2 & 2 & 1.3 \\
Range & $0.3-1.2$ & $0.6-1.3$ & $1.2-1.7$ & $0.6-1.9$ & $1.3-2$ & 2 & $0.4-1.3$ \\
\hline
\end{tabular}

